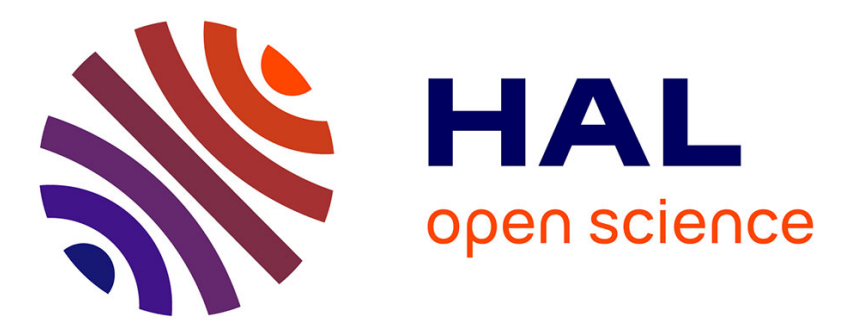

\title{
Germination in five shrub species of Maritime Pine understory-does seed provenance matter?
}

\author{
Vasques, Maia, Pedro, Santos, V. Vallejo, J. Keizer
}

\section{To cite this version:}

Vasques, Maia, Pedro, Santos, V. Vallejo, et al.. Germination in five shrub species of Maritime Pine understory-does seed provenance matter?. Annals of Forest Science, 2012, 69 (4), pp.499-507. 10.1007/s13595-012-0206-3 . hal-00930855

\section{HAL Id: hal-00930855 https://hal.science/hal-00930855}

Submitted on 1 Jan 2012

HAL is a multi-disciplinary open access archive for the deposit and dissemination of scientific research documents, whether they are published or not. The documents may come from teaching and research institutions in France or abroad, or from public or private research centers.
L'archive ouverte pluridisciplinaire HAL, est destinée au dépôt et à la diffusion de documents scientifiques de niveau recherche, publiés ou non, émanant des établissements d'enseignement et de recherche français ou étrangers, des laboratoires publics ou privés. 


\title{
Germination in five shrub species of Maritime Pine understory-does seed provenance matter?
}

\author{
Ana Vasques • Paula Maia • Mariana Pedro • \\ Conceição Santos $\cdot$ V. Ramón Vallejo $・$ J. Jacob Keizer
}

Received: 24 November 2011 / Accepted: 2 April 2012 /Published online: 8 May 2012

(C) INRA / Springer-Verlag France 2012

\begin{abstract}
- Context Maritime Pine forests cover important mountain areas in Portugal and are known to be a particularly fireprone forest type. Understory composition plays an important role in maintaining biodiversity and ecosystem services after recurrent wildfires.

- Aims This study aims to improve the knowledge on the germination ecology of understory species of Maritime Pine forests, focusing on the importance of seed provenance, including in relation to germination enhancement by heating.

- Methods The selected species were Cistus ladanifer L., Erica australis L., Erica umbellata L., Pterospartum

Handling Editor: Eric Rigolot

Contribution of the co-authors Ana Vasques: experimental design, data analysis, data collection, writing the paper.

Paula Maia: collaboration in experimental design and species selection, data collection.

Mariana Pedro: internal reviews and data analysis.

Conceição Santos: experimental design, logistical support, supervision. Ramón Vallejo: experimental design, logistical support, supervision. Jacob Keizer: experimental design, data analysis, intermediate reviews, logistical support, supervision.
\end{abstract}

A. Vasques $(\bowtie) \cdot$ P. Maia $\cdot$ M. Pedro $\cdot$ J. J. Keizer

Centre for Environmental and Marine Studies (CESAM),

Department of Environment and Planning, University of Aveiro,

Campus Universitário de Santiago,

3810-193 Aveiro, Portugal

e-mail: ana.vasques@ua.pt

C. Santos

Centre for Environmental and Marine Studies (CESAM),

Department of Biology, University of Aveiro,

Campus Universitário de Santiago,

3810-193 Aveiro, Portugal

\section{R. Vallejo}

Fundación CEAM,

Parque Tecnológico C/Charles R. Darwin,

14-46980 Valencia, Spain tridentatum L. (Willk), and Genista triacanthos Brot. Seeds were collected from two or three distant populations. Besides a control treatment, two heating regimes were applied, i.e., $100^{\circ} \mathrm{C}$ during $5 \mathrm{~min}$ and $80^{\circ} \mathrm{C}$ during $30 \mathrm{~min}$.

- Results Heating treatments significantly enhanced germination in four out of the five species. Differences between provenances were most evident for $C$. ladanifer and $E$. australis, especially following the heating treatments. Overall, the seeds from the southern provenances germinated better and, at the same time, were smaller.

- Conclusion The present results confirmed that seed provenance should not be ignored as a key factor in germination ecology, so that further work is needed to untangle the roles of environmental and genetic factors in the observed differences between provenances.

Keywords Germination - Seed provenance - Maritime Pine ecosystem · Fire-prone shrubs · Cistus ladanifer · Erica australis $\cdot$ Erica umbellata $\cdot$ Genista triacanthos .

Pterospartum tridentatum

\section{Introduction}

Wildfires play an important role in the history of Mediterranean ecosystems and, as a consequence, Mediterranean plant communities have become fire resilient (Pausas and Vallejo 1999). The resilience of these communities is related to the ability of their principal species to resprout after fire and/or to attain elevated levels of recruitment by germination (Keeley 1986). Based on these traits, Mediterranean species can be divided into seeders and resprouters (Pausas 1999; Verdú 2000), presenting different levels of seedling density and survival following wildfires (Benwell 1998).

In Portugal, Maritime Pine (Pinus pinaster Ait.) plantations have been widely introduced and now are a predominant cover 
type of the northern and central mountain areas in particular (Godinho-Ferreira et al. 2005; Nunes et al. 2005). However, they were strongly affected by wildfires in the past decades and, according to Silva et al. (2009), constitute the most fire-prone forest type in Portugal. Maritime Pine is an obligate seeder and, accordingly, has been found to germinate vigorously after fire, at least in Portugal (Maia et al. 2012b), León (Calvo et al. 2008) and Galicia (Vega et al. 2008). Post-fire seedling recruitment of Maritime Pine can be expected to vary among different regions/ populations, due to differences in germination potential among provenances (Gil et al. 2009; Escudero et al. 2002).

While Maritime Pine recruitment following wildfire has received little research attention in Portugal, post-fire regeneration of the understory species has hither to been largely ignored (Maia et al. 2012a). Knowledge of the germination ecology of understory species is nonetheless important, especially against the background of the likely climate changes and associated increase in fire hazard in Mediterranean regions (Pausas et al. 2008; Piñol et al. 1998). Namely, recurrent fires can markedly reduce the resilience of pine forests (Díaz-Delgado et al. 2002), so that the maintenance of the basic functions of the affected ecosystem may come to depend strongly on the understory species (Fisher et al. 2006; Srivastava and Vellend 2005). Furthermore, species with distinct regeneration traits increase the resilience of the community to subsequent fires (Keeley 1986; Pausas et al. 2004). Besides the importance of shrub species in maintaining biodiversity and ecosystem services (Hartley 2002), the selection of the understory species for introduction in firedegraded communities is not being addressed by the present study because it would need to consider other aspects as well, in particular the species' expected contribution to fuel load built-up and thus, future fire hazard as well as the foreseen management practices (Baeza et al. 2011; Fernandes et al. 2004; Vallejo et al. 2011).

The principal understory species of Maritime Pine plantations in Portugal are shrubs that pertain to the families of Ericaceae and Leguminosae and, to a lesser extent, Cistaceae (Godinho-Ferreira 2005). Five species were selected for the present study, i.e., two Ericaceae, two Leguminosae, and one Cistaceae species. A key factor in selecting the two Ericaceae and the two Leguminosae species was the comparison of the aforementioned, two main types of post-fire regeneration traits, i.e., of an obligate seeder or weak resprouter vs. a facultative resprouter or strong resprouter. In addition to the information underlying the classification of the five selected species in seeders and resprouters (Reyes et al. 2009; Paula and Pausas 2008), there is some evidence that provenance plays a role in the germination potential of one of the studied species, i.e., Erica australis (Cruz et al. 2003). This evidence, however, is limited to nearby populations in Spain. Such differences in germination potential between seed provenances can be related to seed morphological features, in particular seed size (González-Rabanal and Casal 1995; Moreira et al. 2010). Hanley et al. (2003) found smaller seeds to be more tolerant to high temperatures than larger seeds. Nonetheless, under field conditions, the lesser tolerance of bigger seeds may be compensated by their capacity to emerge from greater depths (Bond et al. 1999).

The principal aim of this study is to get more insight in the germination of fire-adapted Mediterranean shrub species, in particular ones that are typical for the understory of Maritime Pine plantations in Portugal. For five selected species from three families, the study has as specific objectives: (1) to assess differences in germination between populations from two or three distant provenances within Portugal; (2) to determine if such differences vary with heating-based pre-treatments that can be expected to enhance the species' germination rates; and (3) to evaluate if such differences are related to morphological seed characteristics, in particular seed size.

\section{Material and methods}

\subsection{Species and harvesting site selection}

The five Mediterranean shrub species selected for this study were E. australis L., Erica umbellata L., Pterospartum tridentatum L. (Willk), Genista triacanthos Brott, and Cistus ladanifer L. Key selection criteria included wide and abundant occurrence in Portugal, elevated seed availability during the foreseen harvesting campaigns and, in the case of the Ericaceae and Leguminosae, contrasting post-fire regeneration traits (obligate seeders and weak resprouters: $E$. umbellata and G. triacanthos; facultative and strong resprouters: E. australis and P. tridentatum). Although perhaps less common in Maritime Pine plantation than the other four species, the obligate seeder $C$. ladanifer $\mathrm{L}$. was selected for being particularly well-adapted to recruitment after fire (Delgado et al. 2008, 2001; Pérez-García 1997). The selected species present distinct types of dormancy. $C$. ladanifer has a hard seed coat that inhibits germination by impeding water entrance in the seed (Ferrandis et al. 1999) and this is also the principal cause of dormancy in the two Leguminosae species (Moreira et al. 2010). The two Ericaceae species, on the other hand, have a permeable seed coat but present physiological dormancy (Vera et al. 2010).

Selection of the harvesting sites was done in two phases. First, using available map information target areas were selected in mountainous areas that corresponded to the northern, central, and southern ranges of the species' distribution areas in Portugal. These areas were then surveyed exhaustively, by car and foot, to locate a sizeable population for the different species, resulting in a total of seven harvesting sites. The species' northern provenances were sampled 
in Castro Laboreiro $\left(41^{\circ} 55^{\prime} \mathrm{N}, 8^{\circ} 13^{\prime} \mathrm{W}\right.$ : Ericaceae and Leguminosae) and Murça $\left(41^{\circ} 25^{\prime} \mathrm{N}, 7^{\circ} 27^{\prime} \mathrm{W}\right.$ : C. ladanifer), their central provenances in Castanheira de Pêra $\left(40^{\circ} 03^{\prime} \mathrm{N}, 83^{\prime} \mathrm{W}\right.$ : E. umbellata, P. tridentatum), Góis $\left(40^{\circ} 09^{\prime} \mathrm{N}, 8^{\circ} 02^{\prime} \mathrm{W}\right.$ : C. ladanifer $)$ and Alvares $\left(40^{\circ} 04^{\prime} \mathrm{N}\right.$, $8^{\circ} 04^{\prime} \mathrm{W}:$ E. australis and $G$. triacanthos), and their southern provenances in Almodovar $\left(37^{\circ} 45^{\prime} \mathrm{N}, 8^{\circ} 07^{\prime} \mathrm{W}\right.$ : C. ladanifer $)$ and $\mathrm{Mu}\left(37^{\circ} 37^{\prime} \mathrm{N}, 8^{\circ} 08^{\prime} \mathrm{W}\right.$ : Ericaceae, Leguminosae). The harvesting sites of each species were thus at least $200 \mathrm{~km}$ apart, minimizing the probability of gene flow occurrence and ensuring marked differences in climatic conditions (Slatkin 1987).

\subsection{Seed harvesting, handling, and treatments}

Seed harvesting was done in various field campaigns during June and July 2009. At each harvesting site, mature seeds were collected from 10 or, if not possible, at least 5 mother plants, which were selected randomly but avoiding those with clear signs of disease. In the laboratory, seeds were manually separated from fruits and other unwanted residues, using sieves, and carefully inspected for external signs of damage and immaturity. The selected seeds were then stored in paper bags under dark and low-moisture conditions for 4-6 months until the beginning of the experiments.

In three instances, the harvesting procedure ended up with insufficient mature seeds to warrant the inclusion of the respective provenance in this study. This was the case for the northern provenances of the two Leguminosae species and for the south provenance of E. umbellata. The northern populations of the two Leguminosae species were comparatively small, on the one hand, and, on the other, many of the mother plants had already released the bulk of their seeds at the time of the harvesting campaigns. The fruits of the southern population of E. umbellata mainly comprised seeds with clear signs of immaturity.

Based on prior studies with the same species (Cruz et al. 2003; Delgado et al. 2001, 2008; González-Rabanal and Casal 1995; Pérez-García 1997; Rivas et al. 2006; Valbuena and Vera 2002; Vera et al. 2010), two heating treatments with different temperatures as well as different exposure times were defined that could be expected to enhance the germination of all five selected species. The same two heating treatments were applied to all species to facilitate comparisons between species, especially those of the same family. The treatments comprised heating at a comparatively high temperature for a short period $\left(100^{\circ} \mathrm{C}\right.$ for $\left.5 \mathrm{~min}\right)$ and heating at a lower temperature for a longer period $\left(80^{\circ} \mathrm{C}\right.$ for $\left.30 \mathrm{~min}\right)$. The treatments can be taken to represent a medium- and high-intensity fire, respectively (Reyes and Casal 2008). Heating was done in a standard laboratory oven. Both the heated and untreated seeds were then photographed (using a random selection of 10 seeds per mother plant) and soaked during $24 \mathrm{~h}$ in distilled water.
For each experiment, 15 seeds of each of the five to 10 individual mother plants were distributed in equal numbers over five Petri dishes with agar-agar $(10 \mathrm{~g} / \mathrm{L})$. The Petri dishes were placed randomly in a germination chamber at $24 \pm 2{ }^{\circ} \mathrm{C}$ with a $16 / 8 \mathrm{~h}$ day/night light period. Germination was recorded every week for at least 2 months until no more germination occurred for two subsequent weeks.

\subsection{Data analysis}

Germination response was characterized by germination percentage and time needed to achieve the $90 \%$ of the total germination (T90). In the case of the absence of germination, the maximum duration of the experiment was considered as the T90. Germination response as well as seed size were analyzed first by means of two-way analysis of variance (ANOVA), using provenances and heating treatments as factors. When the assumptions of normality and/or homogeneity of variance underlying ANOVA were not met, the role of provenance and of treatment were analyzed separately. This was done using one-way ANOVA or, for the species with only two provenances, the Student's $t$ test, if needed following transformation of the original data to $\ln$ $(x+1)$ or square root $(x)$. If the underlying assumptions could not be met, the tests' nonparametric equivalentsi.e., the Kruskal-Wallis test $(\mathrm{KW})$ and Mann-Whitney $U$ test (MWU) - were performed instead. Post hoc pair-wise comparisons between provenances and treatments were carried out using the Tukey or Dunn's tests for ANOVA and $\mathrm{KW}$, respectively. All statistical analyses were performed using Statistica, version 9 for Windows (StatSoft Inc.).

\section{Results}

\subsection{Germination}

\subsubsection{Cistaceae: C. ladanifer}

C. ladanifer achieved a very high maximum germination ratio of almost $100 \%$ and its bulk occurred in a period as short as 2 weeks (Fig. 1). The highest germination ratio was found for the southern population following heating at $80^{\circ} \mathrm{C}$ during $30 \mathrm{~min}$. This treatment was also the most effective in breaking seed dormancy in the other two populations.

The germination ratios revealed a significant interaction between provenance and heating treatment (two-way ANOVA, $p=<0.001)$, so that the role of provenance depended on the treatment. In the case of control experiments, no significant differences existed between the three provenances, whereas the opposite was true for the $100^{\circ} \mathrm{C}-$ 5 min treatment (Tukey, $p \mathrm{~s}=<0.001$ ). The $80^{\circ} \mathrm{C}-30 \mathrm{~min}$ treatment produced intermediary results, with significantly 
Fig. 1 Germination percentage (left) and time-to-germination of $90 \%$ of the final germination (T90; right) for C. ladanifer (average and standard deviation) for all provenances and treatments (number of mother plants: north, center, and south=10). Different letters indicate significant differences between provenances within treatments, at $\alpha=0.05$, using Tukey's test

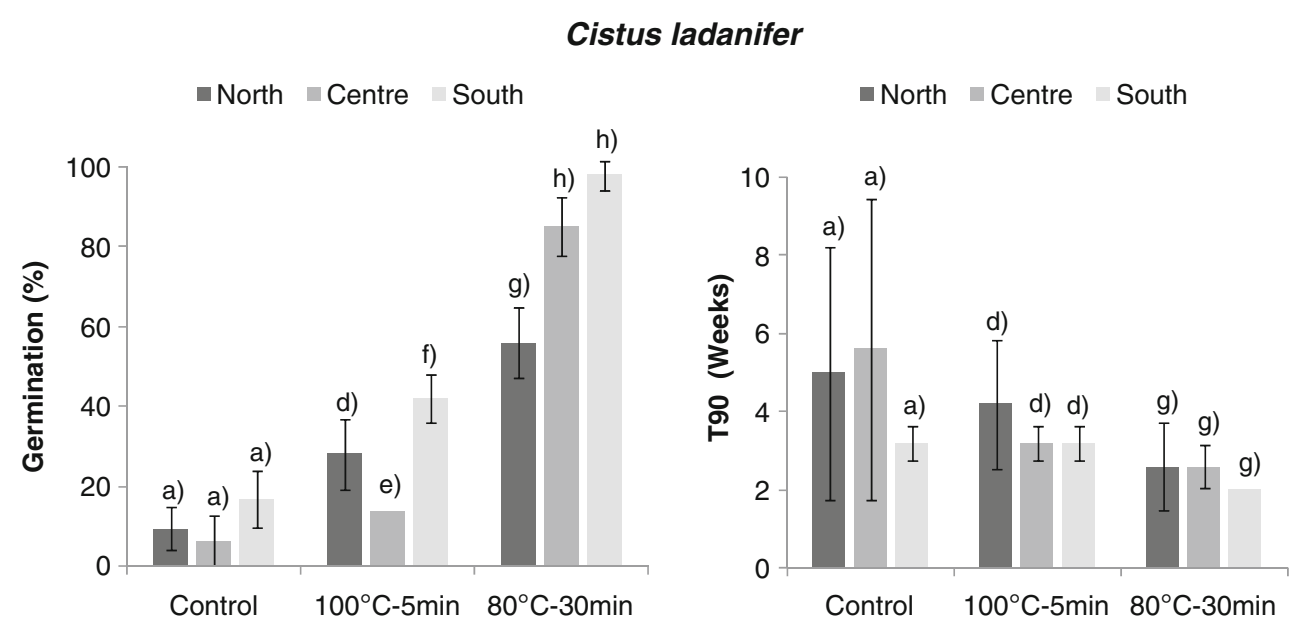

higher germination ratios for the central and southern provenances than for the northern provenance (Tukey, $p \mathrm{~s}=<$ $0.001)$. The $80^{\circ} \mathrm{C}-30 \mathrm{~min}$ treatment was more effective in enhancing germination than the $100^{\circ} \mathrm{C}-5$ min treatment, producing significant effects on all three provenances (Tukey, $p \mathrm{~s}=<0.001$ ) as opposed to on the north and south provenances only ( $p \mathrm{~s}=<0.001-0.70)$.

The time needed for T90 did not vary significantly between the three provenances within the treatments $(p s=0.27-0.42)$. The treatments, on the other hand, presented significant differences in the time needed for germination T90 (KW, $p=<0.01$ ), The post hoc comparisons, however, only identified significant differences for the south provenance, with the $80^{\circ} \mathrm{C}-$ 30 min treatment significantly decreasing the T90 compared to the control and $100^{\circ} \mathrm{C}-5 \mathrm{~min}$ treatment (Tukey, $p s=<0.05$ ).

\subsubsection{Ericaceae: E. australis and E. umbellata}

E. australis reached a markedly lower maximum germination ratio $(45 \%)$ than $C$. ladanifer and also germinated somewhat slower, with a T90 of at least 4 weeks (Fig. 2). A noticeable contrast in final germination ratios existed

Fig. 2 Germination percentage (left) and time-to-germination of $90 \%$ of the final germination (T90; right) for E. australis (average and standard deviation) for all provenances and treatments (number of mother plants: north $=10$, center $=9$, south=10). Different letters indicate significant differences between provenances within treatments, at $\alpha=0.05$, according to Dunn's test between the southern and the other two provenances, at least following heating.

The role of provenance in germination ratios was tested for the individual heat treatments separately, since the assumptions underlying two-way ANOVA were not met. This role was significant for the two heating treatments (ANOVA of $\ln (x+1)$ transformed data: $100^{\circ} \mathrm{C}-5 \mathrm{~min}, p<$ 0.001 ; KW: $\left.80^{\circ} \mathrm{C}-30 \mathrm{~min}: p=0.001\right)$. Both treatments produced significantly more germination of the southern than the other two provenances (Dunn's and Tukey, $p s<0.05$ ). By contrast, the control experiments revealed an ambivalent role of provenance, since the overall test result was significant (KW: $p=<0.01$ ) but all pair-wise comparisons were nonsignificant (Dunn's, $p=>0.05$ ).

The T90 were also found to differ significantly among the three provenances but, again, just for the heating treatments $\left(100^{\circ} \mathrm{C}-5 \mathrm{~min}\right.$ : ANOVA of $\ln (x+1)$ transformed data: $100^{\circ} \mathrm{C}$, $\left.p<0.001 ; 80^{\circ} \mathrm{C}-30 \mathrm{~min}, \mathrm{KW}, p=0.001\right)$. In both instances, these significant differences reflected significantly lower T90s for the south than the other two provenances.

E. umbellata consistently revealed very limited germination, not exceeding $5 \%$ even after 18 weeks (Fig. 3), but

\section{Erica australis}
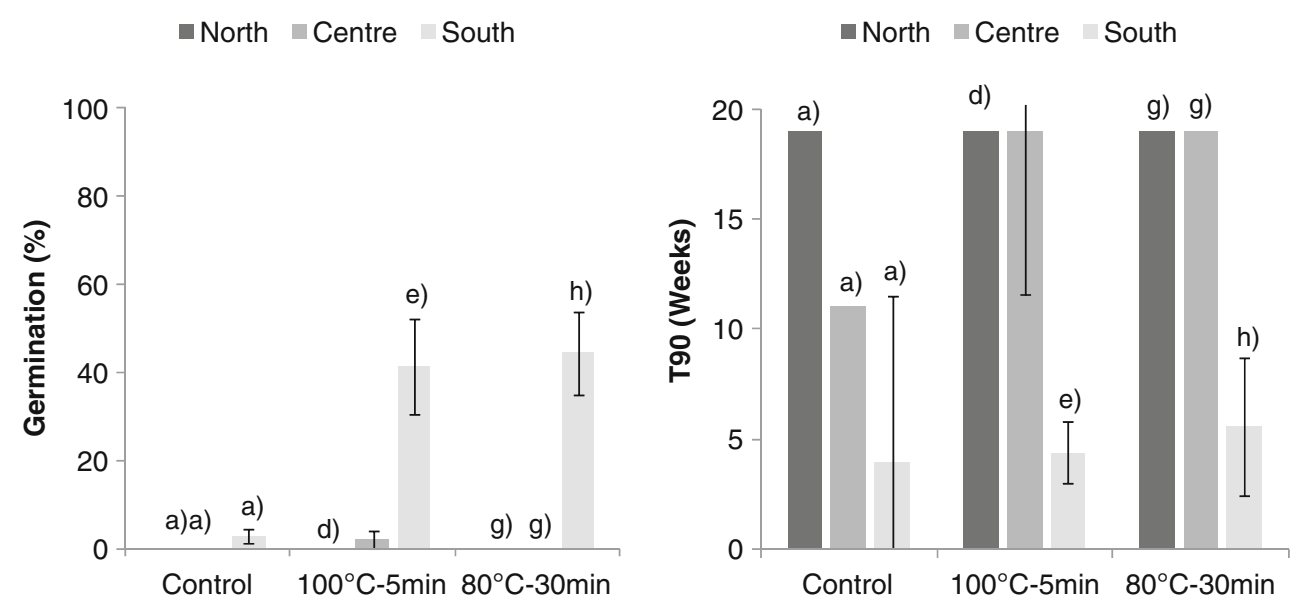
Fig. 3 Germination percentage (left) and time-to-germination of $90 \%$ of the final germination (T90; right) for E. umbellata (average and standard deviation), for all provenances and treatments (number of mother plants: north and center $=0$ ). Different letters indicate significant differences between provenances within treatments, at $\alpha=0.05$, according to the Mann-Whitney $U$ test and Student's $t$ test for germination percentage and T90, respectively

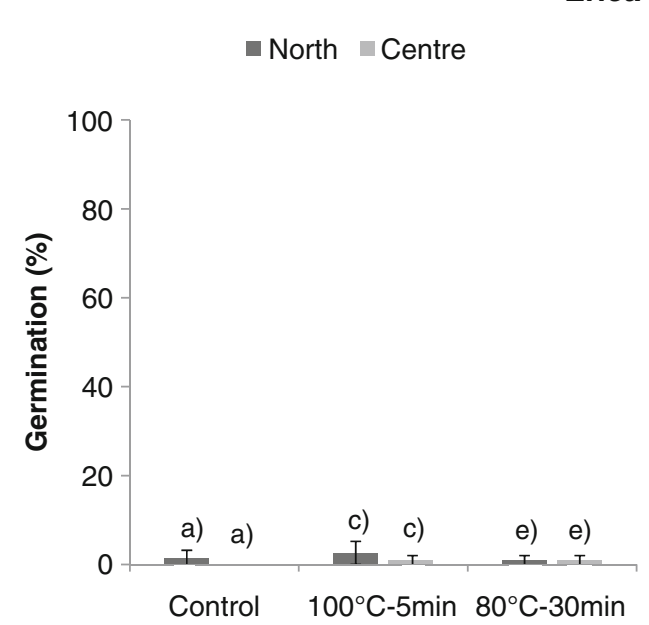

Erica umbellata

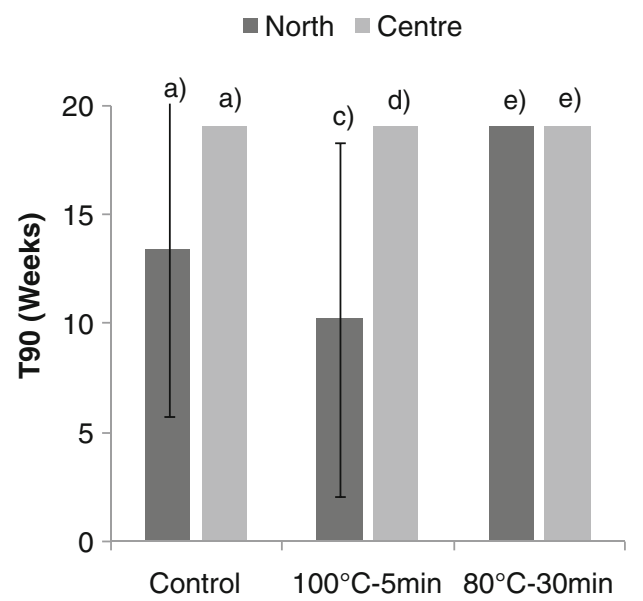

these figures did not differ widely from those of E. australis for the same, northern, and central provenances. Neither provenance ( $t$ test and MWU: $p s=0.20-0.70)$ nor heating regime (ANOVA and $\mathrm{KW}, p \mathrm{~s}=0.34-0.37$ ) had significant effects on the germination ratios. The differences in T90, while shown in Fig. 3, were considered of little interest due to the low germination ratios.

\subsubsection{Leguminosae: P. tridentatum and G. triacanthos}

The maximum germination ratio of $P$. tridentatum $(80 \%)$ was intermediate between that of $C$. ladanifer and that of $E$. australis (Fig. 4). Germination was comparatively slow, however, as T90 amounted to 13 weeks against 4 weeks or less in the cases of $C$. ladanifer and E. australis. While the stimulating effect of heat exposure on germination was apparent, the role of provenance was not.

Like in the case of $C$. ladanifer, germination ratios revealed a significant interaction between provenance and treatment (ANOVA, $p=0.04$ ). Accordingly, the differences between the two provenances were only significant following the $100^{\circ} \mathrm{C}-5 \mathrm{~min}$ treatment (Tukey, $p=<0.01$ vs. $0.31-0.61$ ). The two heating treatments both significantly enhanced germination ratios for the central as well as south provenance (Tukey, $p s=<0.001$ ). However, differences between the two treatments were not significant for either of the two populations (Tukey, $p s=0.41-0.60)$.

The T90 values were consistently smaller for the south than center provenance. This differences were significant for the $80^{\circ} \mathrm{C}-30 \mathrm{~min}$ treatment $(t$ test, $p<0.01$ ) but not for the control or $100^{\circ} \mathrm{C}-5 \mathrm{~min}$ treatment ( $t$ test, $p \mathrm{~s}=0.25-0.48$ ). When analyzing the two provenances, treatments did not influence T90 in a significant manner (ANOVA, $p=0.33$ ).

The results for $G$. triacanthos coincided well with those of $P$. tridentatum in three aspects: (1) a similar maximum germination rate $(80 \%)$, and for the same, $100^{\circ} \mathrm{C}-5 \mathrm{~min}$ treatment; (2) a apparent enhancement of germination by heating; (3) a comparatively slow germination, with T90 frequently exceeding 10 weeks (Fig. 5).

Although this could only be assessed for the control experiments, germination ratios differed significantly among the three provenances (KW, $p<0.01)$. The northern
Fig. 4 Germination percentage (left) and time-to-germination of $90 \%$ of the final germination (T90; right) for P. tridentatum (average and standard deviation) for all provenances and treatments (number of mother plants: center $=10$, south $=5$ ). Different letters indicate significant differences between provenances within treatments, at $\alpha=0.05$, according to Tukey's test for germination percentage and according to Student's $t$ test for T90
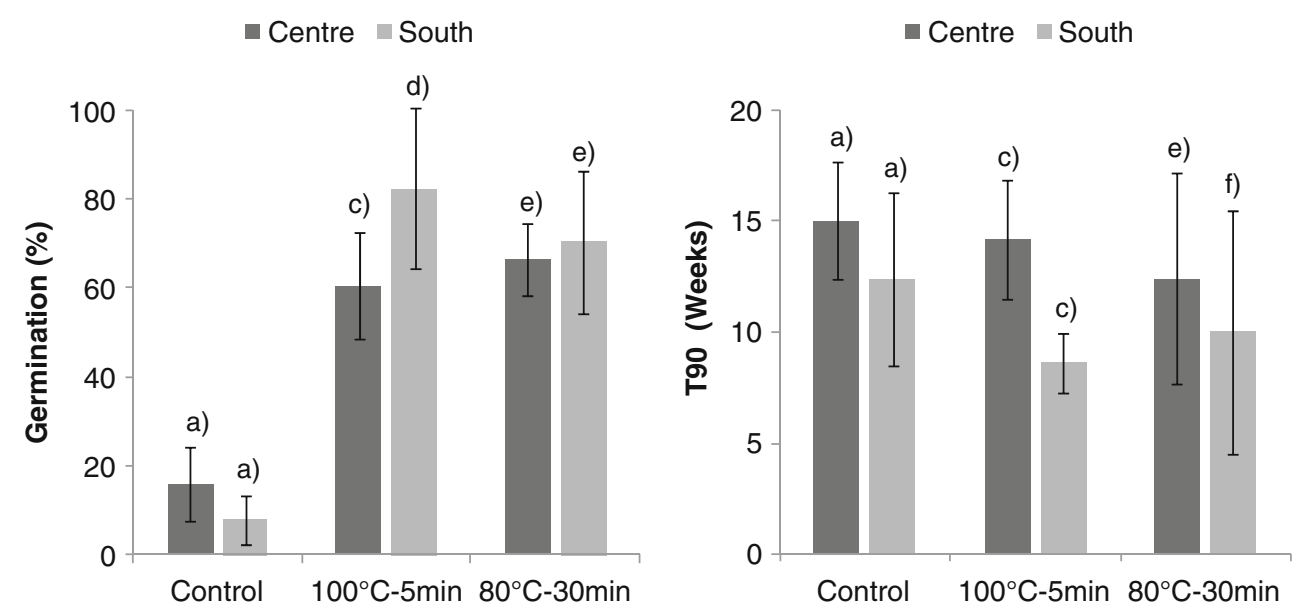


\section{Genista triacanthos}

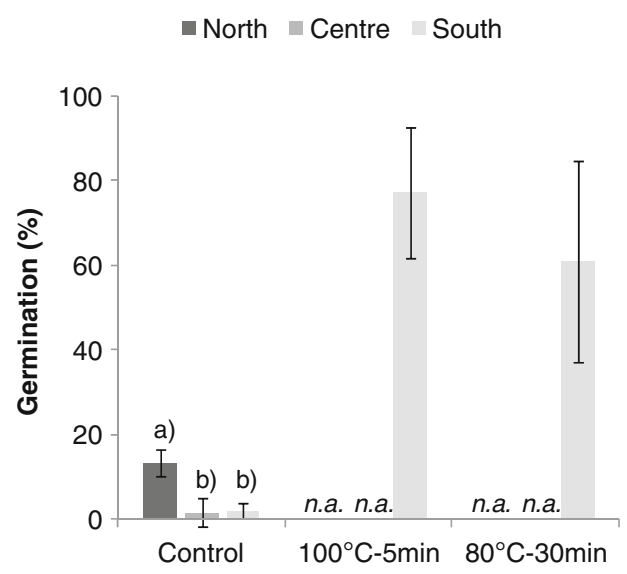

Fig. 5 Germination percentage (left) and time-to-germination of $90 \%$ of the final germination (T90; right) for G. triacanthos (average and standard deviation) for all provenances and treatments (number of mother plants: control - north $=10$, center $=9$, south $=10,100^{\circ} \mathrm{C}-$ 5 min-south $=7 ; 80^{\circ} \mathrm{C}-30 \mathrm{~min}-$ south $=7$ ). Different letters indicate

population exhibited significantly more germination than either of the other two populations (Dunn's, $p \mathbf{s}<0.05$ ). Likewise, germination ratios differed significantly among the three treatments, at least in the case (south) for which this could be evaluated (ANOVA, $p<0.001$ ). The two heating treatments both resulted in a significant enhancement of germination compared to the control experiments (Tukey, $p s=<0.05$ ) but the enhancements themselves were not significantly different (Tukey, $p=0.30$ ). Unlike germination ratios, T90 did not vary significantly with either provenance (KW, control experiments; $p=0.17$ ) or treatment (KW, south provenance; $p=0.52)$.

\subsection{Seed size}

For the four species that revealed a significant role of provenance in germination ratios-i.e., C. ladanifer, E. australis, $P$. tridentatum, and $G$. triacanthos - seed size was also determined (Fig. 6). Without exception, the average seed size of the southern population was smaller than those of the northern and central populations. Statistically significant differences, however, were limited to three of the species and, for each of these species, restricted to the southern population and only one of the other two populations (ANOVA and $t$ test: $p s=<0.001-$ 0.03 ). In the case of $C$. ladanifer, the differences in seed size between provenances were not significant (ANOVA, $p=0.36$ ).

\section{Discussion}

Four of the five shrub species studied here revealed that heating can enhance their germination in a significant manner. For all four species, this evidence for heating-enhanced germination agreed well with the findings of prior studies

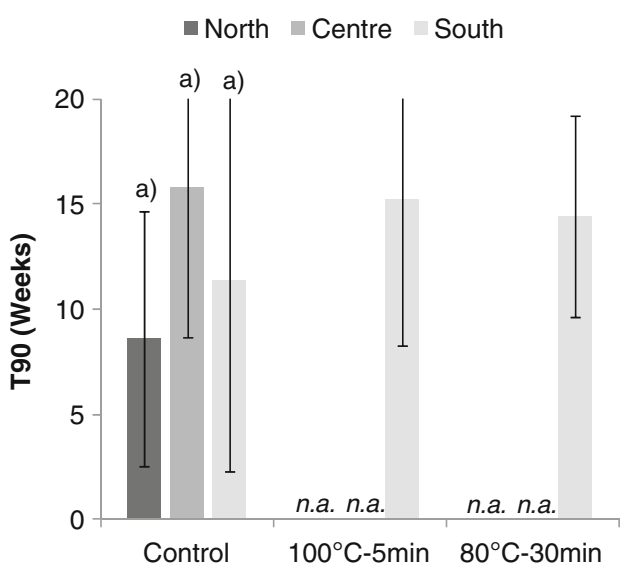

significant differences between provenances within control, at $\alpha=$ 0.05 , according to Dunn's test for germination percentage and according to the KW test for T90 to compare provenances within the control treatment. n.a. indicates that no data existed for the respective provenance

(Cruz et al. 2003; Delgado et al. 2008; Pérez-García 1997; Rivas et al. 2006; Valbuena and Vera 2002; Vera et al. 2010). A more quantitative comparison of this stimulus, however, was seriously hampered by differences in heating regimes and in particular their temperatures, including among the various prior studies as well illustrated for $C$. ladanifer by Pérez-García (1997) and Delgado et al. (2008). Such methodological differences could contribute to the discrepancy between the present results for E. umbellatano apparent response to heating - and those by GonzalezRabanal and Casal (1995) - a positive effect. This is rather unlikely, though, since Gonzalez-Rabanal and Casal (1995), besides the positive effect of heating, found similarly low germination ratios following 5 -min heating at 80 and $110^{\circ} \mathrm{C}$. A strong heating response was certainly not to be expected for E. umbellata. Reyes and Casal (2008) characterized $E$. umbellata's response to a fire stimulus as weak, notwithstanding its plant functional regenerative type of germination dependence. Reyes et al. (2009) even suggested a negative heating effect for $E$. umbellata, presenting a higher germination percentage without treatment (17\%) than after fire (thermic shock or smoke: $6 \%$ ). Moreira et al. (2010) found that smoke rather than heat stimulated the germination of E. umbellata, producing a germination ratio of $57 \%$ as opposed to $0-2 \%$ without treatment as well as for a wide array of heating treatments. Thus, the germination response of $E$. umbellata to heating could vary from weakly positive in the NW region of the Iberian Peninsula (Gonzalez-Rabanal and Casal 1995; this study) to absent in the southern and eastern regions (Moreira et al. 2010). This would imply that the failure to include $E$. umbellata seeds from the south provenance in this study had no notable implications. 


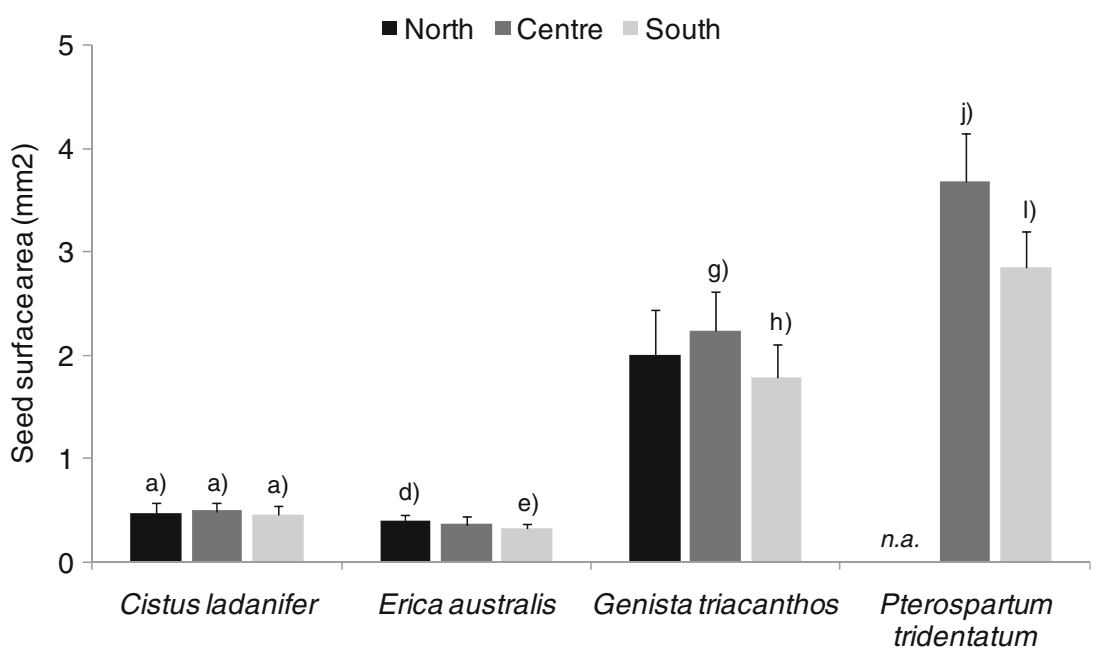

Fig. 6 Seed surface area (average and standard deviation; square millimeter) for the four species revealing significant differences in germination ratios between the provenances (number of mother plants: $C$. ladanifer, north $=10$, center $=10$, south $=10 ;$ E. australis and $G$. triacanthos, north $=$ 10 , center $=9$, south $=10 ; P$. tridentatum, north $=5$, south $=10)$. Different

Unlike the two Ericaceae species, the two Leguminosae species revealed marked similarities in their germination response, in terms of their high-maximum germination ratios $(80 \%)$ and the significant role therein of heating. Rivas et al. (2006) also reported a significant increase following heating for both species, i.e., for the heating treatment that was most similar to that applied here $\left(110^{\circ} \mathrm{C}\right.$ for $\left.5 \mathrm{~min}\right)$. The corresponding germination increase by heating, however, were considerably lower than in this study, especially for G. triacanthos (21\%) but also for P. tridentatum (50\%). Comparison of the present results and those of Rivas et al. (2006) suggested that the exposure time was a key factor in the effectiveness of heating at $80^{\circ} \mathrm{C}$. While the two heating treatments of this study produced similar results, the $80^{\circ} \mathrm{C}-$ $5 \mathrm{~min}$ and $80^{\circ} \mathrm{C}-10$ min treatments of Rivas et al. (2006) lacked a significant effect in G. triacanthos and resulted in roughly twice as little increase in germination for P. tridentatum than the $110^{\circ} \mathrm{C}-5$ min treatment. A marked stimulation of germination by fire/heating was equally found by Reyes et al. (2009) for both Leguminosae species and by Moreira et al. (2010) for G. triacanthos. Also the fire/heating-enhanced germination ratios of these two studies $(P$. tridentatum, $65 \%$; G. triacanthos, 80-90\%) did not differ widely from those reported here. The same applied mutatis mutandis to the germination of the untreated seeds $(<20 \%)$, with the exception of the figure for G. triacanthos in Reyes et al. (2009: $65 \%$ ). This exceptionally high value could involve differences in provenance, being in line with the significantly higher germination ratio of untreated G. triacanthos seeds from the northern than the other two populations studied here. It could further imply that the fire dependence of $G$. triacanthos, as defined by Reyes and letters indicate significant differences between provenances, at $\alpha=0.05$, using Student's $t$ test for $P$. tridentatum and Tukey's test for E. australis and G. triacanthos (after $\ln (x+1)$ transformation); n.a. indicates that no data existed for the respective provenance

Casal (2008), would vary markedly from NW Spain to SE Spain and Portugal.

Ample evidence was provided here that seed provenance should be an important consideration when comparing germination response studies. Four of the five species and all three families studied revealed significant differences between provenances. This proof-of-principle was surprisingly robust against "missing provenances" in the case of two of the three species (P. tridentatum and G. triacanthos). In the case of E. umbellata, on the other hand and as argued above, there was reason to believe that the south provenance would not have revealed a significantly different response from the other two provenances. Further work to verify this hypothesis would seem of interest especially for the implied contrast in germination response with $E$. australis.

The heating treatments proved an essential element in this study, plainly justifying the additional efforts. While the control experiments revealed a significant role of provenance for one species (G. triacanthos), the heating experiments did for three species (C. ladanifer, E. australis, $P$. tridentatum). This heating-dependent role of provenance could be due to the low germination rates in the control experiments, indicating the need for larger sample sizes. Even so, the germination ratios in the control experiments of G. triacanthos were also low but, at the same time, differed significantly.

The current findings sustaining the importance of provenance would seem to fit in well with species' adaptation to a regime of recurrent fires (Paula and Pausas 2008). Namely, the southern populations of three of the species germinated significantly better following heating than the other population(s), on the one hand, and, on the other, fire hazard can be 
expected to increase along the strong climate gradient from north to south Portugal. The divergent results obtained here for $G$. triacanthos (more germination for the northern than other two populations) would plainly justify a follow-up study that tested the heating response of the northern and central populations as well. Such a study would face important logistic challenges. Repeated field campaigns would be needed to harvest sufficient mature seeds, for three reasons in particular: (1) the species' short harvesting period, due to the seed dispersion mechanism of "explosive" pods (Lopez et al. 2000); (2) the limited size of its northern populations in particular; (3) the lack of knowledge on the timing of its seed ripening process, including with respect to the geographical and inter-annual variations therein. Similar considerations would apply in the case of $P$. tridentatum and, except for the first constraint, E. umbellata.

The tendency for seed size to be smallest in the southern populations of C. ladanifer, E. australis, and P. tridentatum, even if not always statistically significant, could suggest a genetic basis for the role of provenance in the species' response to heating. This would need further research, however, since such tendencies could also be the result of environmentally determined phenotypic plasticity, especially because of the large distances between the sampled populations and the associated, marked differences in climatic and meteorological conditions. According to Silvertown (1989) and, more recently, Galloway et al. (2009), differences in seed size between populations are a nonheritable trait. Further work should definitely address the genetic/ phenotypic basis for interpopulation differences in germination behavior and seed characteristics as observed here, especially to sustain forest management for future climate change scenarios (Chambel et al. 2005).

Independent of its genetic or phenotypic origin, seed size could play a role in germination through its relation with seed dormancy. Silvertown (1984) found that smaller seeds often presented stronger dormancy than larger seeds. According to Delgado et al. (2001) and González-Rabanal and Casal (1995), on the other hand, seed size affected the germination response to heating by being related to the resistance of seeds to heating damage. A relation between seed size and resistance to heating damage was also found by Hanley et al. (2003) but in the opposite sense of smaller seeds germinating better than larger seeds at higher temperatures. The latter finding agreed well with the present results, with the southern provenances having smaller seeds as well as higher germination ratios following heating.

\section{Conclusions}

The principal conclusions of this study into differences in germination response between two or three distant populations of five widespread shrub species in Portugal from three different families (C. ladanifer, $E$. australis, and $E$. umbellata, $P$. tridentatum, and G. triacanthos) were the following:

1. germination ratios of untreated seeds were typically less than $20 \%$ for all five species but were markedly enhanced by heating in the case of four of the five species, typically exceeding $50 \%$

2. these same four species also revealed a significant effect of provenance on germination ratios and in three instances this role of provenance would not have been detected without the heating treatments

3. all three families provided pointers towards a possible link between provenance - heating-enhanced germination and seed size but this could equally well involve genetic differences as phenotypic plasticity

4. notwithstanding the gaps in the present data set due to missing provenances, the obtained results made a clear case for the need to contemplate seed provenance in comparing as well as predicting germination response

Acknowledgments The authors are grateful to the Portuguese Institute for Biodiversity and Nature Conservation (ICNB) for the permission to harvest seeds in Portuguese territory. We are also grateful to Banc de Llavors Forestalls de la Generalitat Valenciana and Banco de Sementes do Museu de História Natural de Lisboa, specially to Adelaide Clemente for the provided information about seed processing and storage. The authors also want to acknowledge Isabel Fernandes, Coos Albers, and Diana Vieira for their kind help provided in seed harvesting and Glória Pinto, Armando Costa, Celeste Dias and Helena Oliveira for their technical laboratory support. Finally, we also want to acknowledge the contribution of three anonymous reviewers in improving this manuscript.

Funding This study was funded by the Portuguese Foundation for Science and Technology (FCT) and QREN through PhD grants attributed to A. Vasques (SFRH/BD/47522/2008) and P. Maia (SFRH/BD/ 42168/2007).

\section{References}

Baeza M, Santana V, Pausas J, Vallejo V (2011) Successional trends in standing biomass in Mediterranean basin species. J Veg Sci $22: 467-474$

Benwell A (1998) Post-fire seedling recruitment in coastal heathland in relation to regeneration strategy and habitat. Aust J Bot 46:75101

Bond W, Honig M, Maze K (1999) Seed size and seedling emergence: an allometric relationship and some ecological implications. Oecologia 120:120-132

Calvo L, Santalla S, Valbuena L, Marcos E, Tárrega R, Calabuig E (2008) Post-fire natural regeneration of a Pinus pinaster forest in NW Spain. Plant Ecol 197:81-90

Chambel M, Climent J, Alía R, Valladares F (2005) Phenotypic plasticity: a useful framework for understanding adaptation in forest species. Invest Agrar Sist Recur For 14:334-344

Cruz A, Pérez B, Velasco A, Moreno J (2003) Variability in seed germination at the interpopulation, intrapopulation and intraindividual 
levels of the shrub Erica australis in response to fire-related cues. Plant Ecol 169:93-103

Delgado J, Serrano J, López F, Acosta F (2001) Heat shock, mass dependent germination, and seed yield as related components of fitness of Cistus ladanifer. Environ Exp Bot 46:11-20

Delgado J, Serrano J, López F, Acosta F (2008) Seed size and seed germination in the Mediterranean fire-prone shrub Cistus ladanifer. Plant Ecol 197:269-276

Díaz-Delgado R, Lloret F, Pons X, Terradas J (2002) Satellite evidence of decreasing resilience in mediterranean plant communities after recurrent wildfires. Ecol 83:2293-2303

Escudero A, Pérez-García F, Luzuriaga A (2002) Effects of light, temperature and population variability on the germination of seven Spanish pines. Seed Sci Res 12:261-271

Fernandes P, Loureiro C, Botelho H (2004) Fire behavior and severity in a maritime pine stand under different fuel conditions. Ann For Sci 61:537-544

Ferrandis P, Herranz J, Martínez-Sánchez J (1999) Effect of fire on hard-coated Cistaceae seed banks and its influence on techniques for quantifying seed banks. Plant Ecol 144:103-114

Fischer J, Lindenmayer D, Manning A (2006) Biodiversity, ecosystem function, and resilience: ten guiding principles for commodity production landscapes. Front Ecol Environ 4:80-86

Galloway L, Etterson J, McGlothin J (2009) Contribution of direct and maternal genetic effects to life-history evolution. New Phytol $183: 826-838$

Gil L, Lopez R, Garcia-Mateos A, Gonzalez-Doncel I (2009) Seed provenance and fire-related reproductive traits of Pinus pinaster in central Spain. Int J Wildland Fire 18:1003-1009

Godinho-Ferreira P, Azevedo A, Rego F (2005) Carta da Tipologia Florestal de Portugal Continental. Silva Lusitana 13:1-34

Gonzalez-Rabanal F, Casal M (1995) Effect of high temperatures and ash on germination of ten species from gorse shrubland. Plant Ecol 116:123-131

Hanley M, Unna J, Darvill B (2003) Seed size and germination response: a relationship for fire-following plant species exposed to thermal shock. Oecologia 134:18-22

Hartley M (2002) Rationale and methods for conserving biodiversity in plantationforests. For Ecol Manag 155:81-95

Keeley J (1986) Resilience of Mediterranean shrub communities to fires. In: Dell B, Hopkins A, Lamont B (eds) Resilience in Mediterraneantype ecosystems. Dr. W. Junk, Dordrecht, pp 95-112

Lopez J, Devesa J, Ortega-Olivencia A, Ruiz T (2000) Production and morphology of fruits and seeds in Genisteae (Fabaceae) of south west Spain. Bot J Linn Soc 132:97-120

Maia P, Pausas JG, Arcenegui V, Guerrero C, Pérez-Bejarano A, Mataix-Solera J, Varela MET, Fernandes I, Pedrosa ET, Keizer JJ (2012a) Wildfire effects on the soil seed bank of a maritime pine stand-the importance of fire severity. Geoderma. doi:10.1016/j.geoderma.2012.02.001

Maia P, Pausas J, Vasques A, Keizer JJ (2012b) Fire severity as a key factor in post-fire regeneration of Pinus pinaster (Ait) in Central Portugal. Ann For Sci (in press)

Moreira B, Tormo J, Estrelles E, Pausas J (2010) Disentangling the role of heat and smoke as germination cues in Mediterranean Basin flora. Ann Bot 105:627-635

Nunes M, Vasconcelos M, Pereira J, Dasgupta N, Alldredge R, Rego F (2005) Land cover type and fire in Portugal: do fires burn land cover selectively? Landsc Ecol 20:661-673
Paula S, Pausas J (2008) Burning seeds: germinative response to heat treatments in relation to resprouting ability. J Ecol 96:543-552

Pausas J (1999) Mediterranean vegetation dynamics: modelling problems and functional types. Plant Ecol 140:27-39

Pausas J, Vallejo R (1999) The role of fire in European Mediterranean Ecosystems. In: Chuvieco E (ed) Remote sensing of large wildfires in the European Mediterranean basin. Springer, New York, pp 3-16

Pausas J, Bladé C, Valdecantos A, Seva J, Fuentes D, Alloza J, Vilagrosa A, Bautista S, Cortina C, Vallejo R (2004) Pine and oaks in the restoration of Mediterranean lanscapes in Spain: New perspectives for an old practice - a review. Plant Ecol 171:209-220

Pausas J, Llovet J, Rodrigo A, Vallejo R (2008) Are wildfires a disaster in the Mediterranean basin?-A review. Int $\mathrm{J}$ Wildland Fire 17:713-723

Pérez-García F (1997) Germination of Cistus ladanifer seeds in relation to parent material. Plant Ecol 133:57-62

Piñol J, Terradas J, Lloret F (1998) Climate warming, wildfire hazard, and wildfire occurrence in Coastal Eastern Spain. Clim Chang 38:345-357

Reyes O, Casal M (2008) Regeneration models and plant regenerative types related to the intensity of fire in Atlantic shrubland and woodland species. J Veg Sci 19:575-583

Reyes O, Casal M, Rego F (2009) Resprouting ability of six atlantic shrub species. Folia Geobot 44:19-29

Rivas M, Reyes O, Casal M (2006) Influence of heat and smoke treatments on the germination of six leguminous shrubby species. Int J Wildland Fire 15:73-80

Silva J, Moreira F, Vaz P, Catry F, Ferreira P (2009) Assessing the relative fire proneness of different forest types in Portugal. Plant Biosyst 143:597-608

Silvertown J (1984) Phenotypic variety in seed germination behavior: the ontogeny and evolution of somatic polymorphism in seeds. Am Nat 124:1-16

Silvertown J (1989) The paradoxe of seed size and adaptation. Tree 4:24-26

Slatkin M (1987) Gene flow and the geographic structure of natural populations. Sci 236:787-792

Srivastava D, Vellend M (2005) Biodiversity-ecosystem function research. Is it relevant to conservation? Annu Rev Ecol Ev Syst 36:267-294

Valbuena L, Vera M (2002) The effects of thermal scarification and seed storage on germination of four heathland species. Plant Ecol 161:137-144

Vallejo R, Moreira F, Arianoutsou A (2011) Fire ecology and post-fire restoration approaches in southern european forest types. In: Moreira F, Arianoutsou A, Corona P, De las Heras J (eds). Postfire management and restoration of Southern European forests, 1st edn. Managing Forest Ecosystems, v. 24. Springer: New York. pp 93-120

Vega J, Fernández C, Pérez-Gorostiaga P, Fonturbel T (2008) The influence of fire severity, serotiny, and post-fire management on Pinus pinaster Ait. recruitment in three burnt areas in Galicia (NW Spain). For Ecol Manag 256:1596-1603

Vera D, Martin R, Oliva S (2010) Effect of chemical and physical treatments on seed germination of Erica australis. Ann Bot Fennici 47:353-360

Verdú M (2000) Ecological and evolutionary differences between Mediterranean seeders and resprouters. J Veg Sci 11:265-268 